\title{
DINAMIKA SOSIAL KAJI TINDAK PEMBANGUNAN SISTEM PERTANIAN BERKELANJUTAN, TERINTEGRASI DAN MANIDIRI ENERGI (STUDI KASUS DI DESA PAMALAYAN, KECAMATAN BAYONGBONG, KABUPATEN GARUT)
}

\author{
Adi Nugraha, Irfan R. Sudiyana, M. Gunardi Judawinata, dan Ganjar Kurnia \\ ${ }^{1}$ Departemen Sosial Ekonomi Pertanian, Fakultas Pertanian, Universitas Padjadjaran, Bandung \\ Email: adi.nugraha@unpad.ac.id
}

\begin{abstract}
ABSTRAK
Pertanian berkelanjutan dalam tiga dekade terakhir telah menjadi paradigma baru yang memengaruhi arah pembangunan pertanian. Walaupun demikian, praktik-praktik pertanian berkelanjutan memiliki karakter knowledge-intensive dan dinamis sehingga memiliki kecenderungan kegagalan penerapan yang cukup tinggi. Pola program penyuluhan dan diseminasi teknologi pertanian biasanya berdasarkan asumsi linear yang menempatkan petani hanya sebagai 'pengguna pasif' teknologi yang dihasilkan oleh para ahli ilmu pertanian. Penelitian ini difokuskan pada analisa interaksi-interaksi antar aktor di dalam program pengembangan pertanian berkelanjutan, terintegrasi dan mandiri energi di Desa Pamalayan, Garut. Penelitian ini merupakan penelitian deskriptif kualitatif yang menekankan pada kedalaman informasi yang digali. Data primer didapatkan dari proses wawancara mendalam, FGD, dan observasi partisipatif. Bentuk dan perilaku organisasi serta kondisi sosial secara mikro ketika program dijalankan dianalisis dengan menggunakan Actor Oriented Approach. Berdasarkan hasil penelusuran lapangan, salah satu kunci penentu keberhasilan adalah perencanaan dan pelaksanaan program yang menitikberatkan pada aspek social, yang dalam prosesnya dilakukan secara informal. Hal ini masih jarang dilakukan oleh pelaku pembangunan di Indonesia. Konsep partisipatif dalam diseminasi suatu program pada pelaksanaannya seringkali hanya bersifat sementara, dan tidak dilaksanakan secara bertahap dan berkelanjutan. Oleh karena itu, metode disseminasi dengan pendekatan informal yang mengusung lokalitas dan tingginya tingkat partisipasi tineliti dapat dijadikan contoh untuk program-program pembangunan pertanian dan pedesaan.
\end{abstract}

Kata kunci: dinamika sosial, kaji tindak, keberlanjutan, pertanian terintegrasi

\begin{abstract}
Sustainable agriculture within the last decades has been a new paradigm in agriculture development. However, sustainable agriculture practices are still characterised by knowledge intensive in its dissemination, leading to countless failures. The common dissemination processes apply linear way of thinking in its assumptions, putting farmers as 'object for development'. This study analyses the interaction among the actors involved in the sustainable, integrated and resilient farming system development in Pamalayan, Garut. The study employs descriptive qualitative approach, focusing on the depth of gained information. Primary data were collected through indepth interview, FGD, and participant observation. The social condition and form of interaction among related actors were analysed by using Actor Oriented Approach. The results show that the early stage of the dissemination process is one of the key factor in successing the program. This stage was focused in the social aspect of the beneficiaries, which was done through informal approaches. This style of dissemination is seldom to be seen in Indonesia. Participatory concepts are often superficial, neglecting the social sustainability of the programs. Thus, this case shows that paying attention to social aspects and informal dissemination procces play important roles in rural/agricultural development programs.
\end{abstract}

Keywords: social dynamics, action research, sustainability, integrated farming 


\section{PENDAHULUAN}

Pembangunan pertanian berkelanjutan merupakan isu penting strategis yang menjadi perhatian dan pembicaraan serta menjadi prinsip dasar pembangunan diseluruh dunia termasuk Indonesia (Rivai, 2011). Pertanian berkelanjutan didefinisikan sebagai konsep pertanian yang dapat memenuhi kebutuhan pangan dan serat dari hewani maupun nabati dengan cara-cara yang menguntungkan secara ekonomi, adil secara sosial dan ramah terhadap lingkungan (OECD, 2001). Konsep berkelanjutan (sustainability) merujuk pada konsep Sustainable Development yang ditetapkan Brundtland Commission yaitu pembangunan untuk memenuhi kebutuhan saat ini tanpa merusak atau menurunkan kemampuan generasi mendatang untuk memenuhi kebutuhannya (WCED, 1987).

Pengarusutamaan praktik pertanian berkelanjutan telah diejawantahkan dalam kebijakan pemerintah melalui Undang-undang No. 12 Tahun 1992 tentang sistem Budidaya pertanian (Mangoting, 1998). Salah satu faktor yang menjadi titik berat dari kebijakan pemerintah dalam pengarusutamaan konsep pertanian berkelanjutan adalah upaya-upaya diseminasi teknologi yang memungkinkan harmonisasi tiga dimensi di dalam konsep pertanian yang berkelanjutan. Menurut Viatte (2001), dalam rangka menjamin pertanian yang dapat memproduksi pangan yang cukup dengan memperhatikan lingkungan dan pemerataan kesejahteraan, petani membutuhkan pengetahuan, teknologi dan dukungan insentif yang tepat.

Upaya-upaya diseminasi teknologi berkonsep pembangunan pertanian yang dilakukan pemerintah seringkali hasilnya tidak sesuai yang diharapkan. Pola-pola komunikasi penyuluhan/pemberdayaan, ketepatgunaan teknologi, pola pengorganisasian dan knowledge-power gap diduga menjadi faktorfaktor yang memengaruhi keberhasilan program diseminasi teknologi (Röling \& van de Fliert, 1994). Praktik-praktik pertanian berkelanjutan memiliki karakter knowledgeintensive dan dinamis sehingga memiliki kecenderungan kegagalan penerapan yang cukup tinggi. Pola program penyuluhan dan diseminasi teknologi pertanian biasanya berdasarkan asumsi linear yang menempatkan petani hanya sebagai 'pengguna pasif' teknologi yang dihasilkan oleh para ahli ilmu pertanian. Selain itu, program hanya dimaksudkan untuk mentransfer teknologi yang dihasilkan tanpa memperhitungkan pengetahuan yang dimiliki petani dan kondisi sosial dan lingkungan spesifik yang di hadapi sehari-hari oleh pelaku pertanian (l'art de la localité). Petani diperlakukan sebagai objek dalam penyuluhan pertanian konvensional bukan sebagai subjek pelaku aktif dalam menerapkan teknologi.

Dimensi Pertanian berkelanjutan sangat kompleks dan membutuhkan suatu upaya-upaya yang terintegrasi, sistemik dan dinamis (Roling \& Wagemakers, 2000). Hal ini sangat berbeda dengan bentuk-bentuk intervensi program pembangunan pertanian yang sudah dilakukan oleh pemerintah di Indonesia, dimana program-program pembangunan pertanian hanya memfokuskan pada satu tujuan statis saja yaitu meningkatkan produksi dan produktivitas, bahkan sebatas pada faktor tertentu misalnya subsidi pupuk, pembagian alat mesin pertanian dan bibit. Indikator keberhasilan program pembangunan pertanian hanya menunjukkan keberhasilan secara parsial, sedangkan pertanian berkelanjutan memiliki banyak dimensi, masing-masing dengan konstelasi dan kompleksitasnya. Dengan kata lain, tujuan pembangunan pertanian berkelanjutan tidak hanya untuk menjadikan pertanian sebagai upaya pemenuhan kebutuhan semata, tetapi juga harus dapat mensejahterakan pelaku pertanian dan memminimalisir dampak negatif terhadap lingkungan.

Pada tahun 2010-2014, secara umum produktivitas pertanian tanaman pangan (padi jagung kedelai) rata-rata mengalami peningkatan sebesar Produksi $1.56 \% /$ tahun (KEMENTAN, 2015) dan produksi secara nasional untuk daging dan telur masingmasing sebesar 5,98 dan 7,08 \%/thn. Akan tetapi, Jumlah penduduk yang rawan pangan pada tahun 2011 mencapai 78,49 juta orang, bertambah menjadi 83,65 juta pada tahun 2013 (KEMENTAN, 2015). Selain itu meskipun ada pertumbuhan positif pendapatan /kapita pertanian luas maupun sempit masing masing sebesar 5,64 \% dan 6,20\%/tahun pada kurun waktu tahun 2010-2014, secara nominal tingkat pendapatan/kapita petani tersebut masih berada di bawah garis kemiskinan. Hal ini ditunjukkan bahwa pada tahun 2014 misalnya, tingkat pendapatan/kapita pertanian 
dalam arti luas dan sempit masing-masing sekitar Rp 9.032/kapita/hari dan Rp 7.966/kapita/hari; padahal berdasarkan Bank Dunia batas garis kemiskinan adalah pendapatan US\$2/kapita/hari. dari beberapa data tersebut menunjukkan bahwa tingkat ksejahteraan petani masih relatif rendah. Hal ini menunjukkan bahwa program-program diseminasi teknologi pertanian belum dapat memenuhi asas-asas pertanian berkelanjutan karena hanya fokus pada peningkatan produksi tetapi gagal dalam upaya meningkatkan kesejahteraan petani.

Salah satu penyebabnya adalah Polapola program penyuluhan juga masih merujuk pada pola penyuluhan yang dipakai untuk mensukseskan Revolusi Hijau dan Program Swasembada Pangan pada awal 1970-an. Fokus utama dari program-program diseminasi pertanian masih semata-mata mengejar peningkatan produksi dan pemenuhan kebutuhan, dalam hal ini hanya mencapai satu aspek dari pertanian berkelanjutan. Hal ini mengancam keberlanjutan dan upaya menciptakan kemandirian dan kedaulatan sektor pertanian di masa depan. Gejala tersebut dapat ditunjukkan dengan penurunan jumlah tenaga kerja pertanian dan laju konversi lahan pertanian. Kementan, 2015 memaparkan bahwa pada tenaga kerja pertanian pada kelompok umur pemuda (usia 15 sampai 29 tahun) mengalami penurunan dengan rata-rata pengurangan $3.41 \%$ per tahun dan laju konversi lahan pertanian (sawah) mencapai 100 ribu hektare pertahun.

Perubahan pola-pola kehidupan masyarakat dan perkembangan globalisasi tidak dapat diimbangi oleh inovasi-inovasi program diseminasi teknologi pertanian yang dilakukan oleh pemerintah. Program diseminasi teknologi pertanian berkelanjutan belum dilaksanakan pada keadaan yang ideal dan optimal sehingga dampak dari program juga tidak optimal. Program-program diseminasi teknologi pertanian berkelanjutan dapat dikatakan gagal karena kurang merespon kondisi sosial ekonomi yang dinamis. Hal ini tentunya menuntut dilakukannya kajian lebih mendalam mengenai bagaimana sebuah program diseminasi teknologi pertanian dilaksanakan. Jika terdapat kondisi yang berkebalikan dari gejala umum kegagalan yang terjadi didalam program diseminasi teknologi pertanian maka hal tersebut dapat di katakan sebuah fenomena yang menarik untuk dikaji lebih jauh.

Sebagian besar penelitian mengarah pada pengkajian faktor-faktor penyebab terjadinya kegagalan dan kebijakan disekitarnya. Kajian dan penelitian mengenai keberhasilan program sebatas pada upayaupaya bagaimana melakukan justifikasi agar program dapat dilanjutkan dan diperluas cakupannya. Interaksi antar aktor, perilaku organisasi, kondisi ekonomi dan sosial disekitar program yang berhasil kurang diteliti lebih komprehensif oleh para ahli. Oleh karena itu, penelitian ini difokuskan pada analisa kelayakan ekonomi usaha tani pada intervensi program diseminasi teknologi yang dianggap berhasil dan juga proyeksi keberlanjutan, setelah itu dilakukan analisa interaksi-interaksi antar aktor didalam program pertanian, bentuk dan perilaku organisasi serta kondisi sosial ekonomi makro maupun mikro ketika program dijalankan.

Dari hasil penelitian ini diharapkan dapat diidentifikasi bagaimana dan apa saja yang dapat meningkatkan peluang keberhasilan bagi sebuah program diseminasi teknologi pertanian. Hasil penelitian ini juga dapat digunakan sebagai sebuah acuan untuk memperkirakan prospek keberhasilan dari sebuah program dan perencanaan program diseminasi teknologi pertanian berkelanjutan dimasa yang akan datang.

Program diseminasi teknologi pertanian yang menerapkan konsep pertanian berkelanjutan merupakan program yang diinisiasi oleh Lembaga Ilmu Pengetahuan Indonesia (LIPI) melalui program pertanian mandiri energi dengan mengintegrasikan produksi pertanian dan peternakan dengan penggunaan potensi energi terbarukan yang ada di sekitar lokasi program. Program ini mencakup semua dimensi pertanian berkelanjutan, dimensi ekonomi, sosial dan lingkungan. Lokasi pelaksanaan program terdapat di Desa Pamalayan, Kecamatan Bayongbong, Kabupaten Garut. Program ini telah berjalan selama dua tahun dan melibatkan secara aktif petani lokal. Keterlibatan petani tidak hanya sebatas penerima program tetapi petani terlibat dalam penyediaan modal, perencanaan dan pelaksanaan usaha tani. LIPI berperan hanya sebagai penyedia teknologi dan memberikan pelatihan serta membuat model perencanaan 
penerapan teknologi dengan menyesuaikan kemampuan dan kebutuhan petani. Model program seperti ini dapat dikatakan sebagai sebuah inovasi dalam model pembangunan pertanian berkelanjutan.

Program pertanian terintegrasi mandiri energi menunjukkan gejala-gejala keberlanjutan dan keberhasilan karena telah berjalan selama satu tahun dan teknologi yang diberikan dimanfaatkan oleh petani. Suatu program akan dikatakan berhasil jika dapat menghasilkan dampak yang nyata bagi siapa saja yang terlibat dan lingkungan disekitarnya. Hanya saja, belum ada kajian mengenai aspek social dan proses diseminasinya. Untuk itu perlu dilakukan identifikasi terhadap pola pemberdayaan dan interaksi antar aktor di dalam program selama program dijalankan. Untuk dapat menunjukkan program/ intervensi berpengaruh pada para aktor maka perlu dilakukan kajian mengenai kondisi sosial dan ekonomi di sekitar program sehingga dapat diketahui apakah perubahan yang terjadi disebabkan oleh adanya intervensi program atau yang diinginkan oleh program (intended development) atau dipengaruhi oleh perubahan eksternal kondisi sosial ekonomi disekitarnya (unintended impact).

Sebagian besar penelitian mengarah pada pengkajian faktor-faktor penyebab terjadinya kegagalan dan kebijakan disekitarnya. Kajian dan penelitian mengenai keberhasilan program sebatas pada upayaupaya bagaimana melakukan justifikasi agar program dapat dilanjutkan dan di perluas cakupannya. Interaksi antar aktor, perilaku organisasi, kondisi sosial disekitar program yang berhasil kurang diteliti lebih komprehensif oleh para ahli. Dengan demikian, hal yang menjadi permasalahan dalam penelitian ini adalah keberhasilan suatu program yang dipandang sebagai suatu abnormalitas karena pada umumnya program serupa berakhir tidak sesuai dengan apa yang diharapkan. Penelitian difokuskan pada analisa interaksi antar aktor di dalam program pertanian, bentuk dan transformasi perilaku serta kondisi sosial ketika program dijalankan.

Penelitian dimaksudkan untuk mengisi kesenjangan pengetahuan berkaitan dengan pertanyaan riset utama: Bagaimana interaksi antar stakeholder didalam proses diseminasi yang mempengaruhi keberhasilan program pertanian mandiri energi di Desa Bayobong Kabupaten Garut?

\section{METODE PENELITIAN}

Studi yang akan dilakukan berupa studi deskriptif kualitatif pada program diseminasi teknologi pertanian berkelanjutan yang dilaksanakan oleh LIPI di Desa Pamalayan, Kecamatan Bayobong, Kabupaten Garut. Ruang lingkup kajian dalam penelitian ini mencakup analisis dinamika proses diseminasi kegiatan pertanian terintegrasi mandiri energi. Kajian-kajian tersebut akan dianalisis dengan menggunakan metode kualitatif. Metode kualitatif bertujuan untuk mendapatkan informasi secara mendalam mengenai proses diseminasi program.

Validitas data akan dilakukan melalui beberapa metode triangulasi, diantaranya:

1) Triangulasi sumber data yang bertujuan untuk menggali kebenaran informan tertentu melalui berbagai metode dan sumber perolehan data; metode ini akan dilakukan melalui validasi temuan sementara (preliminary findings) yang disosialisasikan kepada para aktor kunci dan peneliti lain untuk melakukan triangulasi data dan menguji validasi dari temuan yang dihasilkan.

2) Triangulasi teori yang bertujuan untuk menjaga hasil akhir penelitian dengan membandingkan 'thesis statement' penelitian ini dengan perspektif teori yang relevan untuk menghindari bias individual peneliti atas temuan atau kesimpulan yang dihasilkan.

Kajian dinamika proses diseminasi program Pertanian Berkelanjutan dan Mandiri Energi akan dianalisis dengan Actor Oriented Approach.

Actor Oriented Approach. Teori Actor Oriented Approach (Long, 2001) juga digunakan untuk mendapatkan proses pengambilan keputusan dari perspektif pelaku. Actor Oriented Approach (AOA) mengembangkan teori struktur-agensi (Giddens, 1976), yang menekankan pada keterkaitan antara kapasitas individu untuk memproses informasi dan mengambil keputusan (agency) dengan struktur lingkungan, sosial, politik, budaya, moral dan ekonomi yang dimiliki suatu individu (structure). Teori tersebut kemudian dikembangan berdasarkan kapasitas aktor dalam memroses dan berperilaku dengan lingkungan serta pengalaman/pengetahuan 
aktor lain dengan cara yang beragam, menyesuaikan dengan prioritas, tujuan, dan keadaan/kondisi aktor tersebut (Long, 2001). "AOA bertujuan untuk memahami petani, dari mulai perilaku bertani hingga keterkaitan antar pelaku 'dalam konteks yang mereka alami/jalani”" (Rhoades, 1984 p. 40-41). Dalam konteks ini, "metode actor oriented, seperti yang dijelaskan Long, sangat berguna dalam mendapatkan infomasi spesifik terkait dengan aktifitas pertanian" (Hebinck \& Ploeg, 1997 p.204).

Pendekatan Actor Oriented Perspective dipadukan dengan konsep Actor-SpacesKnowledge (McGee, 2004) memungkinkan identifikasi pembentukan 'ruang' sebagai hasil interaksi antara pelaku-pelaku yang memiliki pengetahuan dan pengalaman yang beragam. Ruang tersebut menyediakan memungkinkan terjadinya proses transfer pengetahuan, yang dalam pelaksanaannya dapat menginisiasi terbentuknya pengetahuan-pengetahuan baru yang apabila diikuti dengan komitmen dan aktivitas antar pelaku, dapat termanifestasi dalam suatu perubahan perilaku ke arah yang dituju.

\section{HASIL DAN PEMBAHASAN}

Konsep pertanian berkelanjutan, terintegrasi dan mandiri energi merupakan suatu konsep yang holistik, dan membutuhkan investasi tenaga, waktu dan uang yang tidak sedikit. Oleh karena itu, penentuan mitra yang bersedia untuk berbagi investasi dan komitmen dalam merealisasikan konsep ini sangatlah penting. Tahap pertama pembangunan ini dilaksanakan pada tahun 2013, di mana tim sosial melaksanakan pre-survey, untuk memetakan aktor-aktor yang dinilai memiliki potensi untuk dijadikan sebagai mitra dalam pengembangan pertanian berkelanjutan, terintegrasi dan mandiri energi. Pada praktiknya, tim sosial melaksanakan proses ini dengan cara informal. Hal ini dilakukan dengan maksud mempercepat proses pembangunan kepercayaan dengan menghilangkan tembok-tembok formalitas.

Pada tahun 2013 Lembaga Ilmu Pengetahuan Indonesia (LIPI) Bandung menginisiasi program penerapan Iptek pada masyarakat di Desa Pamalayan, Kecamatan Bayongbong, Kabupaten Garut, Jawa Barat. Inovasi teknologi yang diterapkan merupakan manifestasi dari konsep keberlanjutan, integrasi dan mandiri energi yang dicoba untuk diterapkan pada dunia pertanian untuk menyokong keamanan pangan di masa depan. Program tersebut merupakan pilot project yang menerapkan metode action research (Kaji Tindak) dalam proses pelaksanaannya.

Program ini dilaksanakan melalui beberapa tahap. Tahap pertama adalah pemetaan dan identifikasi lokasi dan pelaku yang memiliki potensi untuk dijadikan sebagai mitra yang bersedia berinvestasi secara materi, waktu, tenaga dan pikiran dalam pengembangan konsep pertanian terintegrasi, berkelanjutan dan mandiri energi. Dalam pelaksanaannya, tahap pemetaan ini dilakukan dengan menempatkan disseminator di lapangan untuk berbaur dengan masyarakat, memetakan, membangun jaringan dan kepercayaan, serta menggali informasi dengan pendekatan-pendekatan informal. Tahap ini merupakan tahap yang paling penting untuk kebehasilan program. Oleh karena itu, tim disseminator menginvestasikan 8 bulan waktu kerja demi terkumpulnya informasi yang holistik dan terbangunnya kepercayaan dengan tineliti.

Tahap ke dua adalah sosialisasi program dan penyusunan rencana kerja serta anggaran yang dilaksanakan secara bersama melalui metode partisipatif. Focus Group Discussion (FGD) dan diskusi informal dilaksanakan secara berkala, dengan tujuan membentuk dan menjaga kesamaan persepsi (common ground) antara tineliti dan peneliti mengenai tujuan bersama (common goals) dan rencana tahapan yang akan dilaksanakan. Pada tahap ini pembangunan 'ruang' diskusi sebagai sarana penghasil gagasan dan inovasi juga dilakukan. Pendekatan informal yang didukung oleh kepercayaan yang telah dibangun pada tahap pertama, menyebabkan 'ruang' yang terbangun bersifat fleksibel, tanpa dihalangi oleh batasanbatasan formalitas. Fleksibilitas tersebut meningkatkan tingkat partisipasi tineliti dalam proses penyusunan rencana, sehingga memperlancar aliran informasi dan pembentukan gagasan.

Gagasan-gagasan tersebut kemudian disusun dalam sebuah dokumen perencanaan, yang pelaksanaannya dilakukan pada tahap ke tiga. Pada tahap ini, interaksi antar peneliti dan tineliti telah menentukan lokasi pengembangan dan rencana pembangunan infrastruktur yang dapat mendukung sistem pertanian 
berkelanjutan, terintegrasi dan mandiri energi. Sistem pertanian ini menekankan pada tiga konsep utama yaitu: 1) Keberlanjutan, yang direalisasikan melalui penerapan konsepkonsep pendukung keberlanjutan seperti zero waste, cost reduction, optimalisasi sumberdaya lokal, dan perputaran energi; 2) Integrasi, diterapkan melalui penerapan konsep keseimbangan ekosistem yang berbasis pada hubungan symbiosis mutualism antar tanamantanaman dan tanaman-ternak; dan 3) Mandiri energi, diterapkan melalui penerapan teknologi dan pembangunan infrastruktur penghasil listrik dan gas terbarukan untuk memenuhi kebutuhan energi di tingkat produksi.

Konsep keberlanjutan dalam sistem pertanian ini tidak hanya terbatas pada aktivitas on-farm, tetapi juga di ranah off-farm, yang diwujudkan melalui pelibatan stakeholder lain (bandar, pedagang, hotel, restoran, catering (horeca)) di daerah setempat berdasarkan rekomendasi tineliti dan masyarakat.

Lahan yang dijadikan sebagai lokasi studi merupakan lahan milik bapak Anas dengan luas total 2 hektar. Lahan digunakan untuk empat kandang ayam berukuran $16 \mathrm{~m}$ x6 m (populasi 2000 ekor per kandang), kebun strawberry terbuka $250 \mathrm{~m}^{2}$, kebun strawberry dengan green house berukuran $26 \times 8 \mathrm{~m}$ yang dilengkapi dengan nano drip irrigation system, kebun strawberry polybag dengan ukuran $12 \mathrm{~m}$ x $6 \mathrm{~m}$ dengan jumah 2.500 polybag dengan populasi 10.000 pohon, jeruk dengan populasi 280 pohon, tomat seluas $280 \mathrm{~m}^{2}$ dan kacang rampong $280 \mathrm{~m}^{2}$, serta kandang sapi yang menampung sekitar 20 sapi. Konsep pengaturan tata guna lahan dan penentuan komoditas dihasilkan dari diskusi partisipatif antara peneliti dan tineliti. Hal ini dilakukan untuk menghasilkan konsep tata ruang yang paling cocok dengan kondisi lokalitas setempat.

Listrik hanya digunakan untuk penerangan kandang 10 lampu per kandang dengan kapasitas 14 watt per kandang dan penerangan jalan sebanyak 2 lampu. Lama menyala lampu berkisar antara jam 5 sampai jam 8 malam karena kapasitas aki tidak terisi optimal karena kondisi sudah rusak. Saat ini, telah ditambah satu pembangkit listrik tenaga matahari untuk mendukung operasional green house. Green house dibangun karena produksi strawberry menurun karena curah hujan tinggi yang memicu layu daun sehingga menutunkan produktivitas tanaman. Dengan dibangunnya greenhouse dengan bahan baku pipa paralon 5 $\mathrm{mm}$ dapat melindungi tanaman dari curah hujan tinggi dan menunjukan pertumbuhan daun yang baik dan saat ini, walaupun hujan deras pertumbuhan daun tetap rimbun dan meningkatkan kualitas bunga dan buah menjadi lebih baik.

Dengan adanya peternakan dan pertanian dalam satu kawasan, pak Anas dapat memanfaatkan limbah dari kotoran ayam sebagai pupuk kandang bahkan banyak nya prokduksi, kotoran ternak dapat dimanfaatkan untuk kebun yang terpisah dari kawasan tersebut. 2 musim ternak ayam selama 3 bulan mampu memenuhi kebutuhan pupuk dasar untuk awal periode penanaman baik kentang, tomat atau kol. Dalam satu musim, kotoran ayam yang dihasilkan sekitar 500-550 karung. Kotoran sapi sebelum dijadikan pupuk bias dimanfaatkan sebagai sumber biogas namun belum dapat dimanmaatkan karena belum sempurnanya alat pembuat biogas.

Berdiri nya kawasan pertanian terpadu ini diawali keinginan bapak Anas untuk mendirikan peternakan ayam pedaging. Setelah mencari informasi melalui saudara maka didirikanlah sebuah kandang dengan kapasitas 2000 ekor ayam pedaging dewasa siap potong kemudian ditambah bertahap hingga mencapai 4 buah kandang ayam. Lipi yang sedang mengembangkan pembangkit listrik alternatif mencari lokasi yang cocok di daerah Garut. Lahan pak Anas diperkirakan memiliki kondisi lingkungan yang cocok untuk membangun pembangkit listrik alternatif dengan memanfaatkan enekgi cahaya matahi angin dan biogas karena di lahan tersebut terdapat pula peternakan sapi perah dan sapi pedaging.

Analisis lingkungan yang dilakukan menunjukan kecocokan kondisi lingkungan sehingga memungkinkan dibuatnya pembangkit listrik tersebut. Dengan perjanjian hibah setelah 3 tahun pihak LIPI dan pak Anas setuju untuk membangun pembangkit listrik alternatif tersebut yang akan dimanfaatkan untuk memenuhi kebutuhan listrik peternakanan diantaranya penerangan, pompa air dan sound system untuk menunjang pertumbuhan ayam pedaging. Saat ini penyimpanan listrik mengalami gangguan karena aki mengalami kerusakan dan tidak bisa 
menyimpan daya secara optimal. Pembangkit listrik biogas pun mengalami kerusakan pada penampung biogas dan hanya pembangkit listrik matahari yang baru yang berfungsi dengan baik.

Berdasarkan hasil penelusuran lapangan, salah satu kunci penentu keberhasilan adalah perencanaan dan pelaksanaan program yang menitikberatkan pada aspek sosial. Hal ini masih jarang dilakukan oleh pelaku pembangunan di Indonesia. Konsep partisipatif dalam diseminasi suatu program pada pelaksanaannya seringkali hanya bersifat sementara, dan tidak dilaksanakan secara bertahap dan berkelanjutan. Pada kasus ini, pelaku pembangunan yang dalam hal ini adalah Lembaga Ilmu Pengetahuan Indonesia, memulai kegiatan mereka dengan pembangunan kepercayaan yang diiringi dengan pangkajian kepribadian para petani. Proses awal ini berlangsung lama, dan mengharuskan para disseminator untuk tinggal di lapangan dan bergaul dengan warga jauh sebelum program dimulai. Setelah mereka berhasil mendapatkan kepercayaan warga (dan beberapa warga terpilih berhasil mendapatkan kepercayaan disseminator), maka sosialisasi program mulai dilakukan.

Program disosialisasikan melalui perbincangan informal, lebih kepada berbagi ide untuk mencapai tujuan yang sama. Dengan demikian, potensi yang terdapat di lokasi dapat terlihat, dan optimalisasi pun dirancang secara bersama dengan petani. Selain itu, pendekatan informal yang dilakukan secara berkala juga dapat menyaring petani yang benar-benar layak dan memiliki kesungguhan untuk berpartisipasi dalam program tersebut. Hal ini dapat dilihat dari kesediaan petani untuk turut berkontribusi dalam proses pembangunan dalam bentuk tenaga, lahan, dan bahkan biaya. Walaupun demikian, kelayakan ekonomi dari sistem pertanian berkelanjutan, terintegrasi dan mandiri energi ini masih diragukan. Peneliti melihat beberapa peralatan teknologi canggih yang tidak mungkin dapat dijangkau oleh petani-petani kecil yang menjadi mayoritas petani di Indonesia. Meskipun gaya bertani tersebut menyediakan berbagai pemangkasan biaya produksi dalam jangka panjang, tetapi nilai investasi yang dibutuhkan tidak mungkin dijangkau oleh petani kecil tanpa ada bantuan dari pihak luar.

\section{KESIMPULAN}

Aspek sosial dalam diseminasi suatu program pengembangan masyarakat seringkali dipandang sebelah mata. Proses transformasi perilaku yang timbul dari proses interaksi antara pelaku pengembangan dan petani di lokasi studi dalam tahap-tahap penerapan teknologi merupakan hal yang tidak bisa diabaikan. Dalam kasus ini, secara kronologis terdapat beberapa tahapan yang dapat dikatakan jarang ditemukan dalam praktik-praktik pembangunan pertanian secara umum, khususnya penekanan pada pentingnya tahapan pembangunan kepercayaan dan pemetaan sosial untuk menentukan tineliti yang potensial untuk dijadikan mitra kerjasama dalam kegiatan kaji tindak. Secara umum, pelaksanaan program pembangunan dimulai dengan pendekatan institusional yang diikuti dengan sosialisasi singkat dan pelaksanaan program. Pada sistem pelaksanaan seperti ini, tineliti diperlakukan sebagai objek pembangunan, sehingga program seringkali bersifat hanya sebatas formalitas dan tidak mampu mencapai tujuannya, serta tidak berkelanjutan.

Tranformasi sosial merupakan proses yang kompleks dan membutuhkan waktu yang lama. Oleh karena itu, tahap pemetaan sosial dan penyertaan partisipasi tineliti dalam perencanaan merupakan tahap yang sangat penting. Walaupun demikian, aspek sosial dari kegiatan pembangunan yang bertitik berat pada transformasi soial seringkali diaplikasikan secara parsial. Kasus ini diharapkan dapat memberikan gambaran bagaimana pentingnya peran aspek sosial dalam pembangunan.

\section{UCAPAN TERIMAKASIH}

Terimakasih diucapkan kepada Universitas Padjadjaran yang telah mendanai penelitian ini melalui program Hibah Internal Unpad skema Riset Dosen Pemula Unpad 2017. Terimakasih juga ditujukan kepada Lembaga Ilmu Pengetahuan Indonesia (LIPI) Bandung dan Bapak H. Anas atas kontribusinya dalam proses penelitian ini.

\section{DAFTAR PUSTAKA}

Hebinck, PGM, and JD van der Ploeg. 1997. Dynamics of Agricultural Production. An Analysis of Micro-Macro Linkages. 
in: Haan, de $\mathrm{H}$ and N. Long (eds), Images and realities of Rural Life. Wageningen Perspectives on Rural Transformations, Assen, Royal van Gorcum, 1997, pp. 202-226.

KEMENTAN. (2015). Renstra Kementan 2015-2019. Retrieved from www.kementan.go.id

Long, Norman. 2001. Development Sociology: Actor Perspectives. London and New York: Routledge

Mangoting, D. (1998). Agenda Reformasi Kebijakan di Sektor Pertanian,(12),1215.

OECD. (2001). OECD Workshop on the Adoption of Technologies for Sustainable Farming Systems: Wageningen Workshop Proceedings. OECD. Retrieved from https://books.google.co.id/books?id=UZa3 oAEACAAJ

Ploeg, JD van der, and A. Long (eds). 1994. Born from within: Practice and Perspectives of Edogenous Rural Development. Assen, The Netherlands: Van Gorcum.

Rivai, R. S. (2011). Berkelanjutan di Indonesia Concept and Implemen-tation of Sustainable Agricultural Development in Indonesia, 13-25.
Rogers, Everett, M. (2003) Diffusions of Innovations; Fifth Edition. Simon \& Schuste Publisher.

Roling, N. G., \& Wagemakers, M. A. E. (2000). Facilitating sustainable agriculture: participatory learning and adaptive management in times of environmental uncertainty. Cambridge University Press.

Röling, N., \& van de Fliert, E. (1994). Transforming extension for sustainable agriculture: The case of integrated pest management in rice in Indonesia. Agriculture and Human Values, 11(2), 96-108. doi:10.1007/BF01530451

Viatte, G. (2001). Adoption of Technologies for Sustainable Farming Systems Wageningen Workshop Proceedings. In Adoption of Technologies For Sustainable Farming Systems Wageningen Workshop Proceedings. Wageningen: OECD.

WCED. (1987). Report of the World Commission on Environment and Development : Our Common Future Acronyms and Note on Terminology Chairman's Foreword. Retrieved from www.un-documents.net/our-commonfuture.pdf 
Vol. 2, No. 2, Desember 2017: 291-357 AGRICORE-Jurnal Agribisnis dan Sosial Ekonomi Pertanian 